\title{
Fen Eğitiminde Kavram Karikatürü ile İlgili Çalışmalar Üzerine Bir İçerik Analizi Tuğba TAŞKIN*
}

Öz: Bu çalışmada, Türkiye'de fen eğitimi alanında kavram karikatürü kullanımını konu alan makalelerdeki eğilimleri belirlemek amaçlanmıştır. Çalışmada, ulusal alan yazında "kavram karikatürü” ifadesini içeren 39 makale yayın yılı, araştırma konusu, çalışma grubu, yöntemi, veri toplama araçları ve veri analiz yöntemleri açısından incelenmiştir. Çalışmada içerik analizi yöntemi kullanılmıştır. Analizler sonucunda kavram karikatürleri üzerine en fazla makalenin 2013 yılında yayımlandığı görülmüştür. Makalelerde en büyük oranda güdülen amacın kavram karikatürleri ile yapılan öğretimin bir değişken üzerindeki etkisini incelemek, en fazla araştırılan bağımsız değişkenin ise akademik başarı olduğu, kavram karikatürlerinin araştırma amacı doğrultusunda çoğunlukla 4-6 hafta arasında kullanıldığı görülmüştür. Makalelerin önemli bir kısmında kavram karikatürlerinin fen ve teknoloji dersinde kullanıldığı, örneklem olarak ortaokul öğrencilerinin, sayı bakımından ise küçük örneklemlerin yer aldığı belirlenmiştir. Metodolojik açıdan yapılan incelemede makaleler çoğunlukla nicel yönteme göre, yarı deneysel desende tasarlanmıştır. Veri toplama aşamasındaki eğilim çoktan seçmeli sorular ve likert tipi ölçekler üzerine olmuştur. Veriler analizinde ise araştırmacıların en fazla t-testini tercih ettikleri görülmüştür.

Anahtar Kelimeler: Kavram karikatürü, Fen eğitimi, İçerik analizi

\section{A Content Analysis Related to Studies About Concept Cartoons in Science Education}

Abstract: The aim of this study is to determine trends of articles on the use of concept cartoons in the field of science education in Turkey. In the study, 39 articles containing the expression "concept cartoons" in national literature were examined in terms of publication year, research subject, study group, method, data collection tools and data analysis methods. A content analysis method was used. As a result of the analysis, it

\footnotetext{
*Araş. Gör. Dr. Gazi Üniversitesi, Gazi Eğitim Fakültesi, Fizik Eğitimi Anabilim Dalı, Email:tcopur@gazi.edu.tr Orcid No: 0000-0002-8738-0012.
}

Gönderim:29.09.2020 Kabul:25.02.2021 Kayın:25.04.2021 
was seen that most articles on concept cartoons were published in 2013. It was determined that the main purpose of the articles was to examine the effect of teaching with concept cartoons on a variable and that the most investigated independent variable was an academic achievement, and concept cartoons were mostly used between 4-6 weeks in line with the research purpose. It was seen that concept cartoons were used in science and technology lessons in most of the articles, and there were middle school students as a sample and in terms of number, they consisted of small samples. In the methodological review, the articles were mostly designed in a quasi-experimental design as a quantitative method. The trend in the data collection phase was on multiplechoice questions and Likert type scales. In the data analysis, it was seen that the researchers mostly preferred the t-test.

Keywords: Concept cartoon, Science education, Content analysis

\section{Giriş}

Fen bilimleri doğası gereği soru sormaya, sorgulamaya, merak duygusuna dayanır. Fen öğretimi de doğadaki meydana gelen olayları anlamayı ve anlaşılır duruma getirmeyi temel alır (Lee, Driscoll ve Nelson, 2004). Fen öğretim programlarının yapısına bakıldığında, Köseoğlu ve arkadaşları (2003) gelişmiş ülkelerdeki programların temelinin sorgulamalı-araştırmalı öğretimden meydana geldiğini belirtmiştir. Son yıllarda ülkemizde de fen öğretim programlarının bu anlayışa göre düzenlenmesiyle, öğrenciyi derste aktif kılacak yöntem ve araçlar ön plana çıkmıştır. Öğrenme ortamında görsel ve işitsel boyutlara sahip araçların önemi artmıştır (Bahrani ve Soltani, 2011). Bu araçlardan biri de günlük yaşamda yer alan olayların görsel bir sunumu olarak kabul edilen (Minárechová, 2014) kavram karikatürleridir.

Kavram karikatürleri; öğrenenlere bilimsel düşünce yapısına ulaşmakta yardımcı olma amacı taşıyan, farklı karakterler arasındaki konuşmalardan oluşan, zaman zaman birden fazla doğru cevabı içeren çizimlerdir (Karakuş, 2019). Kavram karikatürleri bilinen karikatürlerden farklı özellikler taşımaktadır. Kavram karikatürleri insanları güldürmek yerine, öğrencileri eğlendirerek sahip oldukları bilgilerini sorgulatır (İnel, Balım ve Evrekli, 2009). Argümantasyon yönteminin bir tekniği olan kavram karikatürlerinde (Martinez, 2004), günlük hayata uyarlanan bilimsel bilgi, görsellerle, karşılıklı konuşmalar şeklinde sunulur (Birişçi, Metin ve Karakaş, 2010). Kavram 
karikatürlerin en önemli özelliği bir duruma ya da konuya yönelik farklı bakış açıları sunmasıdır (Coll, 2005; Stephenson ve Warwick, 2002; Y1lmaz, 2020). Karikatürdeki her karakter günlük yaşamda karşılaşılan bir olaya yönelik yaygın inançlar ya da kavram yanılgıları içerebilen farklı bir açıklamayı savunur (Martinez, 2004; Samkova ve Hospesova, 2015). Böylelikle öğrenciler kendilerini bir tartışma ortamı içerisinde bulur. Bu ortamda soru sormaya yönelten (Morris, Merritt, Fairchough, Birrell ve Howitt, 2007) karikatürler öğrencilerin öğretmen müdahalesine ihtiyaç duymadan argüman üretmesini ve bilimsel düşüncelerinin gelişmesini sağlar (Atasoy, 2017; Long ve Marson, 2003). Öğrencilerin bilgilerini sorgulamalarına ve bilişsel yapılarında düzenlemeler yapmalarına yardımcı olur (Evrekli, 2010).

Kavram karikatürleri ilk olarak Keogh ve Naylor (1999) tarafindan, fen eğitiminde kavram yanılgılarını belirlemek amacıyla geliştirilmiştir. Günümüzde öğrenme, öğretme ve değerlendirme basamaklarında kullanımına yönelik birçok örneği geliştirilmiştir (Chin ve Teou, 2010; Kabapınar, 2009; Sexton, Gervasoni ve Brandenburg, 2009). Siklıkla dersin başlangıcında merak uyandırma, dikkat çekme (Tokcan, 2015) ve süreç içerisinde tartışma başlatma (Cengizhan, 2011; Kabapınar, 2005; Tokcan, 2015) noktasında tercih edildiği görülmektedir. Bunların yanı sıra kavram karikatürlerinin hizmet ettiği amaçlar; bilimsel okuryazarlık geliştirme, gerçek hayatla bilimsel bilgiyi ilişkilendirme, eski öğrenilenlerle yeni bilgileri birleştirme, farklı bakış açılarına saygı gösterme, kanıtlara dayanarak sonuç çıkarma, ders dışında karşılaşılan fen etkinliklerini eğlenceli kılma olarak özetlenebilir (Şaşmaz-Ören, 2009).

Alan yazında kavram karikatürlerini konu alan çalışma bulguları kavram karikatürlerinin akademik başarıyı artırdığını göstermektedir (Akbaş ve Toros, 2016; Ceylan ve Atabek-Yiğit, 2018; Çelik ve Gündoğdu, 2016; Çetin, 2012; Dalacosta; Kamariotaki-Paparrigopoulou, Palyvos ve Spyrellis 2009; Gölgeli ve Saraçoğlu, 2010; Güler, Çakmak ve Kavak, 2013; Korkut ve Şaşmaz-Ören,2018; Köklükaya, Yıldırım ve Selvi, 2016; Murtiningrum, Ashadi ve Mulyani, 2013; Ocak, Islak ve Ocak, 2015; Özyılmaz-Akamca, Ellez ve Hamurcu, 2009; Y1lmaz, 2013; Yin ve Fitzgerald, 2017; Yolcu, 2013). Kavram karikatürlerinin yer aldığı çalışmaların öğrencilerin akademik başarısı üzerinde etkililiğini inceleyen meta-analiz araştırmalarında çalışmaların pozitif 
yönde geniş (Yokuş ve Ayçiçek, 2019) ve orta (Alkış-Küçükaydın, 2019) düzeyde etki büyüklüğüne sahip olduğu belirlenmiştir.

Araştırmalarda kavram karikatürlerinin başarının yanı sıra, birçok farklı bileşen üzerinde de olumlu etkisinin bulunduğu tespit edilmiştir. Örneğin; kavram yanılgılarını belirleme ve gidermede etkili olduğu (Arıkurt, 2014; Atasoy ve Ergin, 2017; Chin ve Teou, 2008; Demirel ve Aslan, 2014; Öztuna Kaplan ve Boyacıoğlu, 2012; Serttaş ve Türkoğlu, 2020; Stephenson ve Warwick, 2002) bildirilmiştir. Ayrıca kavram karikatürleri kullanıldığında öğrencilerin derse olan ilgisinin arttığı (Aydın, 2015; Jamal, Ibrahim ve Surif, 2019; Kaptan ve İzgi, 2014; Oruç ve Teymuroglu, 2011), eleştirel düşünme ve sorgulama becerilerinin geliştiği (Cavagnetto, 2010; Demirci ve Özyurek, 2017; Gül, Köse ve Konu, 2014; Jamal, Ibrahim ve Surif, 2019; Long ve Marson, 2003; Naylor, Keogh ve Downing, 2007; Yin ve Fitzgerald, 2017) görülmüştür. Kavram karikatürleri soyut kavramları somutlaştırma özelliği taşıdığından, özellikle matematik, fizik ve fen derslerinde kavramları anlamayı kolaylaştırdığı (Ateş ve Ören, 2018; Ceylan ve Atabek-Yiğit, 2018; Güngör,2018; Karakuş, 2019; Kirisçioğlu ve Başdaş, 2007; Naylor ve Keogh, 2013; Say ve Özmen, 2018; Sinanoğlu, 2017) belirlenmiştir. Bununla birlikte öğrencilerin derse katılımını sağlamak, konuya dair sahip oldukları ön bilgileri ya da hatalı bilgileri ortaya çıkarmak ve öğrencileri araştırmaya teşvik etmek konularında etkili olduğu bilinmektedir (Evrekli ve Balım, 2010; Naylor ve Keogh, 1999).

Genç (2020), 2007-2019 yılları arasında lisansüstü tezlerini incelediğinde, fen bilgisi eğitimi alanında kavram karikatürlerini üzerine yüksek lisans düzeyinde 37, doktora düzeyinde iki tez çalışmasına ulaşmıştır. Fen eğitimindeki deneysel ve yarıdeneysel çalışmaların akademik başarı üzerine etkisinin incelendiği meta-analiz çalışmalarında ise Yokuş ve Ayçiçek (2020) makale ve bildirilerden oluşan 23 çalışmayı, Alkış-Küçükaydın (2019) makale ve tezlerden oluşan yedi çalışmayı incelemiştir. $\mathrm{Bu}$ verilerden yola çıkarak, kavram karikatürlerinin fen eğitimcileri arasında oldukça ilgi gören bir konu olduğu söylenebilir. Ancak araştırmacılar arasında ilgi gören çalışma konuları zamanla çalışmaların birbirine benzer özellikler göstermesine ve alan yazının kendini sürekli tekrar etmesine neden olabilmektedir (Deng, Chen, Tsai ve Chai, 2011; Lederman, 2007). Bunun önüne geçebilmek için, 
ülkemizin bu çalışma alanında nerede bulunduğunu, kaydettiği aşamaları ve izlediği yöntemleri bilmek gereklidir. Bunun için bu çalışmada, Türkiye'de fen eğitimi alanında kavram karikatürü kullanımını konu makalelerdeki eğilimleri belirlemek amaçlanmıştır. $\mathrm{Bu}$ amaç doğrultusunda alanyazında ilk kez yer aldığı tarihten günümüze kadar olan ve kavram karikatürünü konu alan ulusal makalelerin tamamı incelenmiştir. İnceleme fizik, kimya, biyoloji ve fen bilgisi olmak üzere fen eğitimi alanının tamamını kapsamaktadır. $\mathrm{Bu}$ yönüyle çalışmanın, araştırmacılar ve eğitimciler için kavram karikatürü çalışmaları hakkında kaynak oluşturacağı; alan yazındaki eğilimleri ve eksik kalan noktalara 1şık tutarak, yapacakları çalışmaları tasarlamalarında yol gösterici olacağı düşünülmektedir.

\section{Yöntem}

\section{Araştırmanın Deseni}

$\mathrm{Bu}$ çalışma, ulusal alan yazında fen eğitimi alanında kavram karikatürü kullanımını konu alan makalelerdeki eğilimler hakkında detaylı bir inceleme yapmak amacı taşıdığından, içerik analizi yöntemi temel alınarak tasarlanmıştır. Araştırma verilerini açıklayacak kavram ve ilişsilere ulaşma amacı taşıyan (Yıldırım ve Şimşek, 2008) içerik analizi çalışmaları betimsel içerik analizi, meta-sentez ve meta-analiz olmak üzere üçe ayrılmaktadır (Çalık ve Sözbilir, 2014). Çalışmada belirli bir konuda yapılmış çalışmaların incelenip düzenlenmesi, çalışmalardaki genel eğilimleri ve sonuçları bir bütün olarak değerlendirilmesi şeklinde olarak tanımlanan (Çalık ve Sözbilir, 2014; Selçuk, Palancı, Kandemir ve Dündar, 2014) betimsel içerik analizi tercih edilmiştir.

\section{Verilerin toplanması ve analizi}

Çalışmada incelenen makalelere ulaşmak için ULAKBİM Dergi Park, Türk Eğitim İndeksi, Google Akademik gibi veri tabanlarından yararlanılmıştır. Taramalar, “kavram karikatürü”, “kavram karikatürleri”, “concept cartoon” anahtar kelimeleri kullanılarak, makalelerin başlık, özet, anahtar kelimeler ve metin kısımlarını kapsayacak şekilde tekrarlanmıştır. Böylelikle sadece başlığında değil, içeriğinde de kavram karikatürlerine yer veren makalelere ulaşılmaya çalışılmıştır. Çalışmada incelenecek makaleler ölçüt örnekleme yöntemi ile belirlenmiş; makalelerde şu ölçütler aranmıştır:

- $\quad$ Fen bilgisi, fizik, kimya ya da biyoloji eğitimi alanına ait olması,

- Türkçe veya İngilizce dillerinde yayımlanması, 
• Kavram karikatürü” ifadesini içermesi,

- Tam metninin erişilebilir olması,

• C C C Calışma türünün "araştırma makalesi” olması

Araştırma bulguları bu ölçütleri sağlayan 39 ulusal makaleden oluşmaktadır (Ek1). Taramalar, başlangıcından itibaren 2020 yılının ilk 7 ayına kadar yayınlanmış makaleleri kapsamaktadır.

İncelenecek makaleler belirlendikten sonra, bir excel dosyası oluşturulmuş, öncelikle kimlik bilgileri (yazar isimleri, yılı, dili), ardından amaç, yöntem bilgileri (çalışma deseni, yaklaşımı, örneklemi), veri toplama ve analiz yöntemleri makalelerde yer aldığı ifadelerle bu dosyaya kaydedilmiştir. Belirlenen makalelerin tam metinleri tekrar tekrar incelenmiş, araştırma sorularına uygun olarak kod ve temalar oluşturulmuştur. Kodlar alan yazındaki benzer çalışmalar incelenerek belirlenmiş, incelenen makale sayısı arttıkça geliştirilmiştir. Sonrasında kategorilere ayrılan kodlar, benzer temalar altında toplanmıştır. Makaleler tekrar tekrar incelenerek, temalara son şekli verilmiştir.

Verilerin kodlanması sırasında yöntem, desen, örneklem seçimi için yazarların makalelerde yer verdiği ifadeler kullanılmıştır. Ancak bazı makalelerde özellikle yöntem, desen ve örneklem seçimi bilgilerinin eksik olduğu görülmüştür. Bu makalelere ait eksik bilgiler araştırmacı tarafından, yöntem ve bulgular kısımlarının tamamı incelerek kodlanmıştır. Eksik bilgilerin kodlanmasında yöntem bilgisi bulunmayan, deseninin deneysel veya yarı deneysel desen olduğu belirtilen makaleler için "nicel yöntem" kodu kullanılmıştır. Sadece nitel yöntem kullanıldığı belirtilerek deseni açılanmayan makaleler ve örneklem seçim ölçütü belirtilmeyen makaleler için bu kısımlar boş bırakılmıştır. Bulgular kısmında bu makaleler "belirtilmemiş" olarak sunulmuştur. Makalelere tablolarda M1, M2, .. şeklinde yer verilmiştir.

$\mathrm{Bu}$ çalışmada güvenilirlik; aktarılabilirlik, tutarlılık ve teyit edilebilirlik ölçütleriyle sağlanmaya çalışılmıştır. Aktarılabilirliği sağlamak için araştırmaya dahil edilen makalelerin belirlenme kriterlerinin verilerin toplanma, kodlama ve tema oluşturma süreçlerinin açıklanmasıyla ayrıntılı betimleme yöntemi kullanılmıştır. Tutarlılık için veriler, makalelerde yer aldığı şekliyle, yorum katılmadan kullanılmıştır. Verilerin analizinde yanlılıktan kaçınmak için kodlar ve temalar alan yazındaki benzer çalışmalardan yararlanılarak oluşturulmuştur. Teyit edilebilirlik için incelenen 
çalışmaların listesi sunulmuş ve analizler istenildiği durumda sunulmak üzere arşivlenmiştir. Analiz sonucu elde edilen değerler frekans değerleri olarak her bir kategori için sayısallaştırılmıştır. Verilerin sayısallaştırılması, araştırmanın tekrar edilmesi halinde bulgular arasında karşılaştırma imkanı sunması açısından olduğu kadar, araştırmanın güvenilirliği açısından da önemlidir (Yıldırım ve Şimşek, 2008).

Alan yazında önerildiği şekilde analizlere, sürece hakim olmayan, bağımsız bir uzmanı dahil etmek yerine veriler yinelemeli olarak farklı zamanlarda araştırmacı tarafından tekrar tekrar gözden geçirilmiştir. Böylelikle verilerin, kodların ve temaların doğrulanması, çalışmaların tam ve doğru temsil edilmesi sağlanmıştır (Morse, Barrett, Mayan, Olson ve Spiers, 2002).

\section{Bulgular}

\section{İncelenen makalelere genel bakış}

$\mathrm{Bu}$ kısımda fen eğitiminde kavram karikatürlerinin kullanımını konu alan makalelerdeki eğilimi belirlemek üzere, makalelerin genel özellikleri olan yayımlanma yılı, çalışma alanı, örneklem seçimi vb. incelenmiştir. Makalelerin yayımlandığı yıllara göre dağ 11 เmı Grafik 1'de görülmektedir.

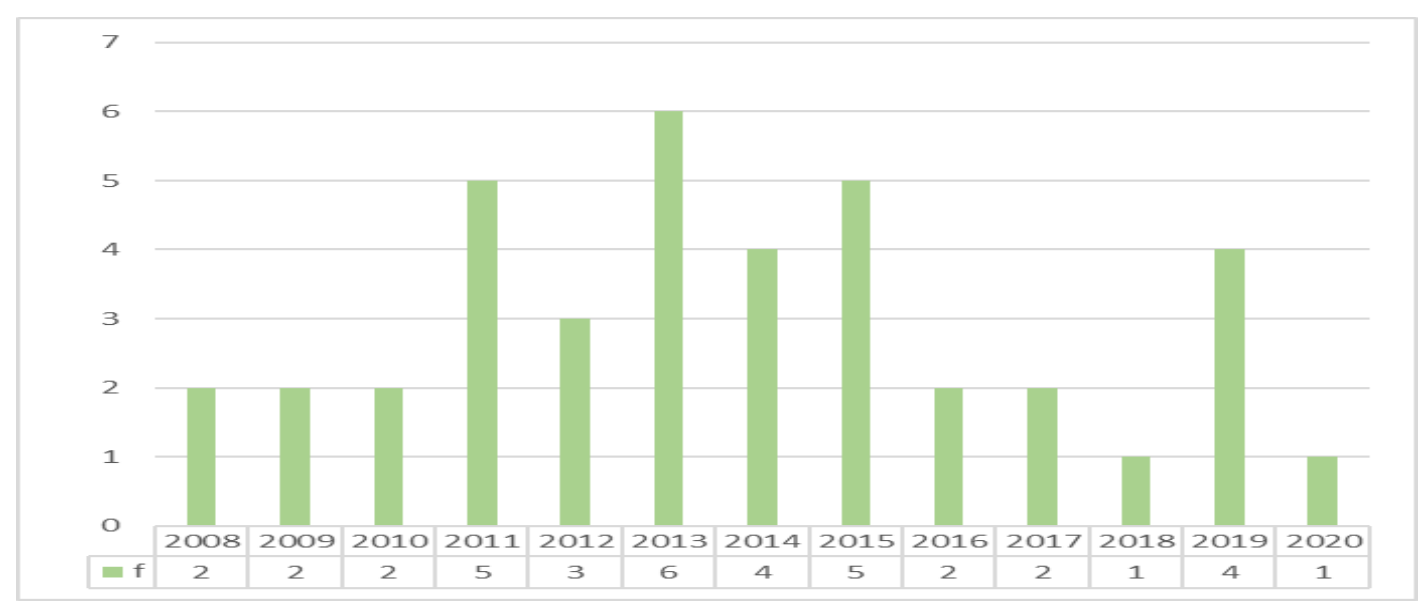

Grafik 1. Makalelerin yıllara göre dağılımı

Grafik 1'de görüldüğü üzere, Türkiye'de kavram karikatürü çalışmaları fen eğitimi alan yazınında 2008'den itibaren yer almaya başlamıştır. 2011 yılından itibaren makale sayısının artmaya başladığı, en fazla makalenin ise 2013 yılında ( $f=6, \% 15,4)$ yayımlandığı görülmektedir. Takip eden yıllarda konuya olan eğilim azalmış, 2019 
YYÜ Eğitim Fakültesi Dergisi (YYU Journal of Education Faculty), 2021; 18(1)622-651,http://efdergi.yyu.edu.tr,

yılında yeniden artış göstermiştir. Bu makalelerin amaçlarına göre dağılımı Tablo 1'de görülmektedir.

Tablo 1. Makalelerin Amaçlarına Göre Dağılımı

\begin{tabular}{|c|c|c|}
\hline Amaç & Makale kodu & f (\%) \\
\hline $\begin{array}{l}\text { Kavram karikatürleri ile yapılan öğretimin bir } \\
\text { değişken üzerindeki etkisini incelemek }\end{array}$ & $\begin{array}{l}\text { M1, M2, M3, M4, M6, M8, M11, M12, } \\
\text { M13, M15, M16, M17, M18, M20, M21, } \\
\text { M23, M30, M31, M32, M33, M34, M37, } \\
\text { M38, M39 }\end{array}$ & $24(61,5)$ \\
\hline $\begin{array}{l}\text { Kavram karikatürleri ile kavram yanılgılarının tespit } \\
\text { etmek ve/ya gidermek }\end{array}$ & $\begin{array}{l}\text { M5, M10, M19, M22, M24, M25, M27, } \\
\text { M28, M29 }\end{array}$ & $9(23,1)$ \\
\hline Kavram karikatürlerine yönelik görüşleri belirlemek & M7, M36 & $2(5,1)$ \\
\hline $\begin{array}{l}\text { Kavram karikatürleri ile öğrencilerin bir konuya } \\
\text { yönelik bilgi düzeyleri/algılarını tespit etmek }\end{array}$ & M26, M35 & $2(5,1)$ \\
\hline Kavram karikatürü testi geliştirmek/değerlendirmek & M9, M14 & $2(5,1)$ \\
\hline
\end{tabular}

İncelenen makaleler amaçları açısından değerlendirildiğinde, amaçların 5 ana kategoride toplanabildiği görülmüştür. Bunlar arasında makalelerin yoğunlaştı̆̆ amaçlardan birinin kavram yanılgılarının belirlenmesi ve/ya giderilmesi konusunda kavram karikatürlerinden yaralanmak olduğu görülmüştür (f=9;\%23,1). En fazla çalışmanın ise $(\mathrm{f}=24 ; \% 61,5)$ kavram karikatürleri ile yapılan öğretimin bir değişken üzerindeki etkisini inceleme amacı doğrultusunda yapıldığı görülmektedir. Çalışmalarda etkisi incelenen bağımsız değişkenler Tablo 2'de görülmektedir.

Tablo 2. Makalelerde Yer Alan Bağımsız Değişkenler

\begin{tabular}{|c|c|c|}
\hline Bağımsız değișken & Makale kodu & $f(\%)$ \\
\hline Akademik başarı & $\begin{array}{l}\text { M1, M3, M6, M12, M15, M17, M18, M30, M32, } \\
\text { M33, M34, M37, M38, M39 }\end{array}$ & $14(35,9)$ \\
\hline Kavramsal anlama/öğrenme & M2, M4, M11, M18, M20, M21, M23 & $7(17,9)$ \\
\hline Tutum & M3, M6, M12, M32, M37 & $5(12,8)$ \\
\hline Sorgulayıcı öğrenme becerisi algıs1 & M13, M32, M34, M38 & $4(10,3)$ \\
\hline Motivasyon & M6, M31, M32 & $3(7,7)$ \\
\hline Problem çözme becerisi algı düzeyi & M11 & $1(2,6)$ \\
\hline Bilimsel süreç becerileri & M16 & $1(2,6)$ \\
\hline Argüman geliștirme düzeyleri & M17 & $1(2,6)$ \\
\hline Öğrenmenin kalıcılı̆̆ı & M33 & $1(2,6)$ \\
\hline
\end{tabular}

Tablo 2'de görüldüğü üzere, makalelerde en fazla araştırılan değişkenin öğrencilerin akademik başarısı ( $\mathrm{f}=14 ; \% 35,9)$ olduğu görülmektedir. Daha sonra kavram karikatürleriyle yapılan öğretimin öğrencilerin kavramsal anlamaları $(f=7 ; \% 17,9)$ ve 
YYÜ Eğitim Fakültesi Dergisi (YYU Journal of Education Faculty), 2021; 18(1)622-651,http://efdergi.yyu.edu.tr,

konuya karşı tutumları $(\mathrm{f}=5 ; \% 12,8)$ üzerindeki etkisi araştırılmıştır. Bilimsel süreç becerileri, argümantasyon geliştirme düzeyleri vb değişkenlere ise oldukça sınırlı çalışmada yer verilmiştir. Bu amaçlar doğrultusunda fen eğitimindeki kavram karikatürü çalışmaları Tablo 3'te görülen öğrenim alanlarına yönelik tasarlanmıştır.

Tablo 3. Makalelerin Öğrenme Alanlarına Göre Dağılımı

\begin{tabular}{|c|c|c|c|}
\hline Ders & Konu & Makale kodu & $f(\%)$ \\
\hline \multirow{13}{*}{$\begin{array}{l}\text { Fen ve } \\
\text { teknoloji }\end{array}$} & Madde ve 1s1 & M10, M11, M13, M31, M32, M34 & \multirow{13}{*}{$\begin{array}{c}28 \\
(71,8)\end{array}$} \\
\hline & Yaşamımızdaki elektrik & M3, M16, M21 & \\
\hline & Iş1k ve ses & M12, M20, M30 & \\
\hline & İnsan ve çevre & M6, M8, M35 & \\
\hline & Vücudumuzdaki sistemler & M1, M33 & \\
\hline & Canlılar dünyasını gezelim, tanıyalım & M15, M37 & \\
\hline & Hücre bölünmeleri ve kalıtım & M17, M25 & \\
\hline & Biyoçeşitlilik & M2 & \\
\hline & Kütle ve ağırlık & M5 & \\
\hline & Güneş sistemi ve ötesi & M18 & \\
\hline & Gök cisimlerini tanıyalım & M24 & \\
\hline & Sera etkisi ve küresel ısınma & M27 & \\
\hline & Ya basınç olmasaydı? & M38 & \\
\hline \multirow{4}{*}{ Fizik } & Doğru akım devreleri & M19 & \multirow{4}{*}{$4(10,3)$} \\
\hline & Işık & M22 & \\
\hline & Geometrik optik & M23 & \\
\hline & Kuvvet ve hareket & M28 & \\
\hline \multirow{3}{*}{ Kimya } & Atom ve iyon yarıçapı & M4 & \multirow{3}{*}{$3(7,7)$} \\
\hline & Kimyasal denge & M9 & \\
\hline & Is1, sicaklık & M29 & \\
\hline \multirow{3}{*}{ Biyoloji } & Fen öğretimi laboratuvarı & M7 & \multirow{3}{*}{$3(7,7)$} \\
\hline & Bitkilerde solunum, fotosentez & M26 & \\
\hline & Bağışıklık sistemi & M39 & \\
\hline $\begin{array}{l}\text { Fen ve } \\
\text { teknoloji } \\
\text { öğretimi-1 }\end{array}$ & Fen ve teknoloji dersi kazanımları & M14 & $1(2,6)$ \\
\hline
\end{tabular}

Makaleler öğrenme alanlarına göre incelendiğinde, en fazla eğilimin kavram karikatürlerini fen ve teknoloji dersinde kullanmaya yönelik olduğu görülmüştür (f=28;\%71,8). Genellikle bu dersteki fizik konuları üzerine yoğunlaşılmıştır. Buna rağmen fizik dersinde ya da kimya, biyoloji gibi diğer fen derslerinde kavram karikatürü kullanımına yönelik sınırlı sayıda çalışma yapılmıştır. 
$\mathrm{Bu}$ öğrenme alanlarında kullanılan kavram karikatürleri 12 çalışmada $(\% 30,8)$ başlı başına bir öğretim materyali olarak, 3 çalışmada (M12, M25, M34; \%7,7) kavram haritası, yapılandırılmış grid vb. alternatif ölçme araçlarıyla bir arada kullanılmıştır. 2'şer çalışmada $(\% 5,1)$ animasyonu destekli kavram karikatürü (M8, M13), argümantasyon sürecine dayalı kavram karikatürü (M17, M20) ve kavram karikatürleriyle zenginleştirilmiş çalışma yaprakları (M19, M23) tercih edilmiştir. 1'er çalışmada $(\% 2,6)$ ise kavram karikatürleri destekli, 5E modeli (M27), probleme dayalı öğrenme (M31) ve analojiler-tahmin-gözlem açıklama teknikleri (M37) kullanılmıştır.

\section{İncelenen Makalelerde Tercih Edilen Metodolojik Yaklaşımlar}

Bu bölümde kavram karikatürlerini fen eğitiminde kullanmayı konu alan ulusal makaleler metodolojik yaklaşımları açısından incelenmişstir. Makalelerde incelenen bir değişken de örneklemdir. Makalelerin örneklemleri örneklem belirleme yöntemi, örneklem düzeyi ve örneklem büyüklüğü açısından değerlendirilmiştir. Örneklem belirleme yöntemine göre yapılan incelemede dört çalışmada (M5, M11, M15 ve M16) basit seçkisiz örneklem, üç çalışmada (M7, M14, M35) amaçlı örneklem yöntemlerinin kullanıldığ̣ görülmüştür. Bir çalışmada (M26) örneklemin gönüllülük esasına göre belirlendiği, 31 çalışmada ise örneklem belirleme yönteminden bahsedilmediği görülmüştür. Örneklem düzeylerine ait bilgiler Tablo 4'te sunulmuştur.

Tablo 4. Makalelerin Örneklem Düzeyine Göre Dağılımı

\begin{tabular}{llll}
\hline $\begin{array}{l}\text { Örneklem } \\
\text { düzeyi }\end{array}$ & Seviye/Bölüm & Makale kodu & f (\%) \\
\hline İlkokul & 4. sinıf & M5, M15 & $2(5,1)$ \\
Ortaokul & 5. sinıf & M2, M20, M37 & $26(66,7)$ \\
& 6. sinıf & M1, M3, M11, M30, M32, M34 & \\
& 7. sinıf & M6, M8, M12, M16, M18, M21, M24, M27, M31, & \\
& 8. sinıf & M33, M36, M38 & \\
Lise & 9. sinıf & M10, M13, M17, M25, M35 & $2(5,1)$ \\
& 11. sinıf & M4 & $9(23,1)$ \\
Lisans & Fen bilgisi öğretmenliği & M39, M7, M19, M22, M23, M26, M28, M29 & \\
& Sunıf öğretmenliği & M14 &
\end{tabular}

Tablo 4'te görüldüğü gibi, kavram karikatürü çalışmalarında araştırmacıların eğiliminin ortaokul öğrencileri (f=26; \%66,7) üzerine olduğu anlaşılmaktadır. Makalelerde çoğunlukla 7. sınıf öğrencileri ile çalışılmıştır (f=12; \%30,8). Daha sonra öğretmen adaylarına ( $\mathrm{f}=9 ; \% 23,1)$ odaklanan fen eğitimi araştırmacılarının ilkokul ve 
YYÜ Eğitim Fakültesi Dergisi (YYU Journal of Education Faculty), 2021; 18(1)622-651,http://efdergi.yyu.edu.tr,

lise düzeylerinde sınırlı sayıda çalışma yaptıkları belirlenmiştir. Örneklemini öğretmen adaylarının oluşturduğu çalışmaların ( $f=9$ ) ise makalelerin neredeyse tamamı $(f=8)$ fen bilgisi öğretmen adaylarıyla yürütülmüştür. Fizik, kimya, biyoloji gibi diğer fen branşlarında öğrenim gören öğretmen adaylarıyla yürütülen çalışmalar bulunmamaktadır. Düzeyleri belirlenen bu örneklemlerin büyüklük açısından incelenmesi Tablo 5’te görülmektedir.

Tablo 5. Makalelerin Örneklem Büyüklüğüne Göre Dağılımı

\begin{tabular}{llc}
\hline $\begin{array}{l}\text { Örneklem } \\
\text { büyüklüğü }\end{array}$ & Makale kodu & f (\%) \\
\hline 0-50 kişi & M1, M2, M3, M5, M7, M8, M9, M10, M15, M18, M24, M27, M29, M32, & $18(46,2)$ \\
51-100 kişi & M34, M36, M38, M39 & $13(33,3)$ \\
101-150 kişi & M19, M23 & $2(5,1)$ \\
151-200 kişi & M14, M26 & $2(5,1)$ \\
201-250 kişi & M22, M28 & $2(5,1)$ \\
251 kişi ve üzeri & M11 & $1(2,6)$ \\
\hline
\end{tabular}

Yapılan incelemede, araştırmacıların çalışmalarını çoğunlukla 0-50 kişilik ( $\mathrm{f}=18$; \%46,2) ve 51-100 kişilik (f=13; \%33,3) örneklemlerle yürüttüğü belirlenmiştir. Sadece bir çalışmada (M11) 553 kişiden oluşan örneklem bulunduğu tespit edilmiştir. Özellikleri belirlenen örneklemlerde yürütülen çalışmaların yöntem ve desenlerine göre incelenmesi sonucunda Tablo 6 oluşturulmuştur.

Tablo 6. Makalelerde Kullanılan Araştırma Yöntem ve Desenleri

\begin{tabular}{lllc}
\hline Yöntem & Desen & Makale kodu & f (\%) \\
\hline \multirow{4}{*}{ Nicel } & Yarı deneysel & M1*, M2*, M3, M4, M6*, M11*, M12*, M13*, & \\
& & M16*, M17*, M18*, M19*, M20*, M21*, & 28 \\
& Deneysel & M23*, M25*, M31*, M34*, M37*, M38* & $(71,8)$ \\
& Tarama & M15, M24*, M27*, M30*, M32*, M33*, M39* & \\
\hline \multirow{4}{*}{ Nitel } & Olgu bilim & M26 & \\
& Durum çalışması & M7 & 7 \\
& Doküman analizi & M10 & $(33,3)$ \\
& İçerik analizi & M35 & \\
\hline Karma & Belirtilmemiş & M22, M28, M36 & $1(2,6)$ \\
\hline Belirtilmemiş & Siralı açıklayıcı tasarım & M5 & $3(7,7)$ \\
\hline$*$ Yöntem bilgisi & makalede belirtilmemiş, araştırmacı tarafından kodlanmıştır. &
\end{tabular}


YYÜ Eğitim Fakültesi Dergisi (YYU Journal of Education Faculty), 2021; 18(1)622-651,http://efdergi.yyu.edu.tr,

Tablo 6'dan, kavram karikatürlerini konu alan çalışmaların önemli bir kısmının (f=28; \%71,8) nicel yöntemde tasarlandığı görülmektedir. Çalışmaların neredeyse yarısında yarı deneysel ( $\mathrm{f}=20 ; 51,3)$ tercih edilmiştir. Nitel yöntem 7 çalışmada $(\% 33)$, karma yöntem ise 1 çalışmada $(\% 2,6)$ kullanılmıştır. İncelenen makalelerin 24’ünde yönteme, 3’ünde desene, 3’ünde ise hem yönteme hem de desene yönelik açıklama yapılmamıştır.

Tablo 7. Kavram Karikatürlerinin Kullanılma Süreleri

\begin{tabular}{|c|c|c|}
\hline Süre & Makale kodu & f $(\%)$ \\
\hline 1-3 hafta & M3, M4, M8, M19, M23, M24, M27, M30 & $8(20,5)$ \\
\hline 4-6 hafta & $\begin{array}{l}\text { M7, M11, M13, M15, M16, M17, M20, M21, M31, M33, M34, M36, } \\
\text { M38 }\end{array}$ & $13(33,3)$ \\
\hline 7-9 hafta & M12, M25 & $2(5,1)$ \\
\hline 10 hafta ve üzeri & M14 & $1(2,6)$ \\
\hline Belirtilmemiş & $\begin{array}{l}\text { M1, M5, M6, M9, M10, M18, M22, M26, M28, M29, M32, M35, } \\
\text { M37, M39 }\end{array}$ & $14(35,9)$ \\
\hline
\end{tabular}

Kavram karikatürlerinin kullanılma süreleri de makalelerde bir değişken olarak incelenmiş, bulguları Tablo 7'de sunulmuştur. Buna göre, kavram karikatürlerinin en fazla 4-6 hafta arasında ( $\mathrm{f}=13 ; \% 33,3)$ kullanıldı̆̆ görülmektedir. Bir öğretim dönemi boyunca kavram karikatürlerinin kullanıldığı sadece 1 makale (M14) olduğu belirlenmiştir. 14 makalede $(\% 35,6)$ ise süre hakkında bilgi bulunamamıştır. $\mathrm{Bu}$ makalelerde verilerin toplanmasında kullanılan ölçme aracı türleri incelenmiş ve Tablo 8'de sunulmuştur.

Tablo 8. Makalelerde yararlanılan veri toplama araç ve teknikleri

\begin{tabular}{llc}
\hline Veri toplama aracı/tekniği & Makale kodu & f (\%) \\
\hline Çoktan seçmeli soru & M1, M4, M6, M10, M11, M12, M15, M16, M17, M18, M29, M30, & $18(46,2)$ \\
Likert tipi ölçek & M32, M33, M34, M37, M38, M39 & $9(23,1)$ \\
Açık uçlu soru & M3, M6, M12, M13, M31, M32, M34, M37, M38 & $6(17,9)$ \\
Görüşme & M2, M8, M22, M25, M28, M35 & $6(17,9)$ \\
Kavram karikatürleri & M7, M17, M18, M25, M27, M36 & $6(17,9)$ \\
2 aşamalı test & M14, M22, M24, M26, M28, M35 & $6(17,9)$ \\
3aşamalı test & M4, M5, M9, M20, M21, M27 & $2(5,1)$ \\
Çalı̧̧ma yaprağı & M19, M23 & $1(2,6)$ \\
\hline
\end{tabular}

Tablo 8’e göre, kavram karikatürü konulu makalelerde verilerin toplanmasında en fazla çoktan seçmeli sorulardan ( $f=18 ; \% 46,2)$ ve likert tipi ölçeklerden ( $f=9 ; \% 23,1)$ yararlanılmıştır. Bunun yanı sıra çalışmaların önemli bir kısmında ( $\mathrm{f}=23 ; \% 59,0)$ veriler 
YYÜ Eğitim Fakültesi Dergisi (YYU Journal of Education Faculty), 2021; 18(1)622-651,http://efdergi.yyu.edu.tr,

tek bir ölçme aracıyla toplanmıştır. Araştırma verileri 11 çalışmada $(\% 28,2)$ iki farklı, 4 çalışmada $(\% 10,3)$ üç farklı, 1 çalışmada $(\% 2,56)$ ise dört farklı veri toplama aracı kullanarak desteklenmiştir. Bu araçlarda toplanan verilerin analizinde kullanılan yöntem ve teknikler Tablo 9’da görülmektedir.

Tablo 9. Makalelerde Kullanılan Veri Analiz Yöntemleri

\begin{tabular}{|c|c|c|c|}
\hline \multicolumn{2}{|c|}{ Veri analizi yöntemleri/teknikleri } & \multirow{2}{*}{$\begin{array}{l}\text { Makale kodu } \\
\text { M1, M2, M4, M5, M6, M16, M17, } \\
\text { M20, M21, M24, M26, M27, M30, } \\
\text { M38, M39 }\end{array}$} & \multirow[t]{2}{*}{$f(\%)$} \\
\hline \multirow{7}{*}{ Kestirimsel } & $\mathrm{t}$ testi & & \\
\hline & Mann-Withney U & $\begin{array}{l}\text { M2, M3, M4, M12, M15, M18, } \\
\text { M26, M31, M32, M34 }\end{array}$ & \multirow{6}{*}{$27(69,2)$} \\
\hline & Wilcoxon & M2,M3, M4, M12, M31, M32, M34 & \\
\hline & Tekli varyans analizi (ANOVA) & M6, M13, M16, M33, M37 & \\
\hline & Kovaryans analizi (ANCOVA) & M13, M23, M33 & \\
\hline & Çoklu kovaryans analizi (MANCOVA) & M11 & \\
\hline & Kruskall Wallis & M26 & \\
\hline Betimsel & Frekans/Yüzde & $\begin{array}{l}\text { M9, M17, M19, M20, M25, M27, } \\
\text { M28, M29, M35, M36 }\end{array}$ & $10(25,6)$ \\
\hline Nitel & $\begin{array}{l}\text { İçerik analizi } \\
\text { Nitel betimsel analiz }\end{array}$ & $\begin{array}{l}\text { M7, M14, M17, M22 } \\
\text { M5, M10, M18 }\end{array}$ & $7(17,9)$ \\
\hline \multirow{3}{*}{ Diğer } & Faktör analizi & M13 & \multirow{3}{*}{$3(7,7)$} \\
\hline & Madde analizi & M21 & \\
\hline & Belirtilmemiş̧ & M8 & \\
\hline
\end{tabular}

Çalışma kapsamındaki makaleler veri analiz yöntem ve teknikleri açısından incelendiğinde, kestirimsel istatistik kullanımın makalelerin büyük bir kısmında yer aldığı görülmüştür (f=27; \%69,2). Kendi aralarındaki dağılıma bakıldığında ise en fazla t-testinin ( $\mathrm{f}=15 ; \% 38,5)$ ve Mann-Whitney $\mathrm{U}(\mathrm{f}=10 ; \% 25,6)$ analizinin kullanıldı̆̆ görülmüştür. Bunun yanı sıra, 10 makalede $(\% 25,6)$ frekans/yüzde istatistiğine yer verilmiştir.

\section{Tartışma ve Sonuç}

Bu çalışmada, Türkiye'de fen eğitimi alanında kavram karikatürü konulu makaleler çeşitli değişkenler açısından incelenmiştir. Yapılan incelemeye göre, kavram karikatürleri fen eğitimi alan yazınında 2008 'den itibaren yer almaya başladığı ve günümüzde hala devam ettiği görülmektedir. Lisansüstü tezleri araştırıldığında, bu konuda yayımlanmış olan ilk çalışmaların yüksek lisans düzeyinde ve 2007 yılına ait (örneğin: Baysarı, 2007; Durmaz, 2007) olduğu belirlenmiştir. Bu döneme ait makaleler de tez çalışmalarına paralel olarak alan yazında yer bulmuş olabilir. 2011-2015 yı1ları 
ulusal alan yazında kavram karikatürü makalelerinin artış gösterdiği dönem olmuş, en fazla makale ise 2013 yılında yayımlanmıştır. 2015'ten sonra sayıların yeniden azaldığı görülmüştür. Benzer bulgulara ulaşan Çetinkaya ve Taşar (2018) bu durumu, fen eğitimi araştırmacıların 2015 yılı itibarıyle belirgin şekilde STEM eğitimi araştırmalarına yönelmeleriyle açıklamışlardır. Diğer taraftan Genç'in (2020) fen bilgisi alanındaki tezleri incelediği çalışmasında ise kavram karikatürlerini konu alan tez sayısının 20172019 yılları arasında artış gösterdiği görülmektedir. Bu durumda tez çalışmalarının makale olarak ulusal alan yazına yansımadığı anlaşılmaktadır. Çiltaş, Güler ve Sözbilir (2012), bu duruma sebep olarak yenilenen ulusal dergi standartlarına göre yayın yapmanın zorlaşmasını ve araştırmacıların yurt dışı dergilere yönelmesini işaret etmiştir.

İncelenen 39 makalede en fazla eğilim gösterilen amacın kavram karikatürleri ile yapılan öğretimin bir değişken üzerindeki etkisini incelemek ( $\mathrm{f}=24 ; \% 61,5)$ olduğu belirlenmiştir. Makalelerde en fazla araştırılan değişkenler ise öğrencilerin akademik başarıları $(\mathrm{f}=14 ; \% 35,9)$ ve kavramsal anlamaları $(\mathrm{f}=7 ; \% 17,9)$ olmuştur. Yokuş ve Ayçiçek (2020), kavram karikatürleri ile akademik başarı arasındaki ilişkiyi inceleyen çalışmalarda birbiriyle uyumlu olmayan bulgular elde edildiğini bildirmiştir. $\mathrm{Bu}$ çalışmada incelenen unsurlardan biri olan kavram karikatürlerinin kullanılma süresi, bu uyumsuz sonuçları açıklayabilir. İncelenen çalışmalarda kavram karikatürlerinin en fazla 4-6 hafta arasında ( $\mathrm{f}=13$; \%33,3) kullanıldı̆̆ ve bu süreler sonunda etkisinin araştırıldığı görülmektedir. Ancak alan yazında akademik başarıya etki edebilmesi için kavram karikatürlerinin en az sekiz hafta süreyle kullanılması gerektiği bildirilmektedir (Yokuş ve Ayçiçek, 2020). Bu durumda daha güvenilir sonuçlar elde edilebilmesi için yapılacak yeni çalışmalarda kavram karikatürlerinin daha uzun sürelerde uygulanması önerilmektedir. Buna ek olarak, Karadağ (2009) eğitim alanında akademik başarının üzerinde en fazla çalışılan tema olduğuna işaret etmektedir. Tasarlanacak yeni çalışmalarda kavram karikatürleri ile bilimsel süreç becerileri, kritik düşünme becerileri, epistemolojik inançlar gibi makalelerde oldukça sınırlı olarak yer almış olan farklı değişkenler arasındaki ilişkileri belirlemek üzerine tasarlanabilir.

Fen eğitiminde kavram karikatürlerinin hangi öğrenme alanlarında kullanıldığı bu çalışmada araştırılan değişkenlerden biri olmuştur. Analizler sonucunda incelenen makalelerin önemli bir kısmında kavram karikatürlerinin fen ve teknoloji dersinde (f=28; \%71,8) kullanıldığı görülmüştür. Bununla uyumlu olarak örneklemleri 
çoğunlukla ortaokul öğrencileri (f=26; \%66,7) oluşturmaktadır. Makalelerde yine sıklıkla öğretmen adaylarından oluşan örneklemleri ise fen bilgisi öğretmen adaylarının oluşturduğu belirlenmiştir. Fen bilgisi alanında kavram karikatürlerine gösterilen ilginin fizik, kimya, biyoloji gibi derslerde ve daha üst öğrenim düzeylerinde gösterilmemiş olması alan yazındaki boşluğa işaret etmektedir. Makalelerde yer alan örneklemlerin bir başka özelliği olarak, araştırmacıların çoğunlukla 0-50 kişilik ( $\mathrm{f}=18 ; \% 46,2)$ ve 51-100 kişilik ( $\mathrm{f}=13 ; \% 33,3)$ örneklemlerle araştırmalarını yürüttüğü belirlenmiştir. Bu bulgu ile alan yazında sıklıkla karşılaşılmaktadır (Çiltaş ve diğ., 2012; Polat, 2013; Ulutaş ve Ubuz, 2008; Yavuz, 2017). Genel olarak Türkiye'de eğitim alanında yapılan çalışmalarda küçük örneklemlerin yer aldığı bilinmektedir (Arık ve Türkmen, 2009; Göktaş ve diğ., 2012; Selçuk ve diğ., 2014; Yalçın, Yavuz ve Dibek, 2016). Çalışmaların genellikle bir şehir ya da bir okulu kapsamasının bu durumun sebeplerinden biri olduğu düşünülmektedir (Akaydın ve Çeçen, 2015).

Bu çalışmada yapılan metodolojik incelemede fen eğitiminde kavram karikatürü konulu makaleler yöntem, desen veri toplama araçları ve analiz yöntemleri açısından değerlendirilmiştir. Şimşek ve arkadaşları (2008), yüksek lisans tezlerini inceledikleri çalışmada tezlerdeki en büyük sorunun yöntem kısmında gerekli bilgilerin verilmemesi olduğunu belirtmiştir. Bu çalışmada da aynı durumla karşıllaşılmış; makalelerin önemli bir kısmında araştırmanın yöntemine $(\mathrm{f}=24, \% 61,5)$ yönelik bilgi verilmediği görülmüştür. Bazı makalelerde araştırma deseni $(f=3, \% 7,7)$, bazılarında ise hem yöntemi hem de deseni ( $\mathrm{f}=3, \% 7,7$ belirtilmemiştir. $\mathrm{Bu}$ bilgilerin belirlendiği makalelerin büyük bir kısmının ( $\mathrm{f}=28 ; \% 71,8)$ nicel yöntemde tasarlandı̆̆ 1 görülmektedir. Çalışmaların neredeyse yarısında yarı deneysel $(\mathrm{f}=20 ; \% 51,3)$ tercih edilmiştir. Eğitim araştırmalarında genel eğilimin deneysel ve yarı deneysel desen kullanımına yönelik olduğu bilindiğinden (Çalık, Ünal, Coştu ve Karataş, 2008; Çiltaş, Güler ve Sözbilir, 2012; Şimşek ve diğ., 2008; Temel, Şen ve Yılmaz, 2015; Yavuz, 2017) bu bulgu şaşırtıcı olmamıştır. Nitel $(\mathrm{f}=7$; \%33) ve karma $(\mathrm{f}=1 ; \% 2,6)$ desenlerle tasarlanmış araştırma sayısının ise azlığı göze çarpmaktadır. Yöntem açısından yurt dışında yapılan araştırmalara bakıldığında, birinci sırada nitel yöntemin, ikinci sırada karma yöntemin tercih edildiği görülmektedir. Ülkemizde ise özellikle eğitim alanında nitel araştırmaların daha az tercih edildiği görülmektedir (Arık ve Türkmen, 2009; Göktaş ve diğ., 2012; Şimşek ve diğ., 2008). Bu durum, nitel araştırmaların doğal 
ortamda ve derinlemesine çalışmayı gerektirmesine ve araştırmacılarının daha uzun zaman ve fazla çaba harcamaktan kaçınmalarıyla açıklanmıştır (Alshamrani ve Aldahmash, 2020). Nitel yöntem ve teknikler, araştırmaları derinleştirmek ve fenomenleri daha anlaşılır kılmak suretiyle alana katkı sağladığı gerekçesiyle sıklıkla önerilmektedir (Alshamrani ve Aldahmash, 2020; Göktaş ve diğ., 2012; Slack, Lewis ve Bates, 2004). Karma yöntemin ise araştırma sorusunun tek yöntemin sunduğundan daha açık ve anlaşılır olarak ortaya koyduğu savunulmaktadır (Gülbahar ve Alper, 2009; Molina-Azorin ve Cameron, 2015). Kavram karikatürleri kullanmanın etkilerini daha iyi aydınlatmak ve alan yazında daha etkili kullanılmasını sağlamak açısından yapılacak yeni çalışmalarda nitel yöntemlerden de yararlanılması önerilebilir.

Verilerin nasıl toplandığına dair yapılan inceleme sonucunda kavram karikatürü konulu makalelerde verilerin en fazla çoktan seçmeli ( $f=18$; \%46,2) ve likert tipi ( $f=9$; $\% 23,1)$ sorulardan oluşan ölçekler yardımıyla toplandığg belirlenmiştir. Bunun yanı sıra çalışmaların önemli bir kısmında $(\mathrm{f}=23 ; \% 59,0)$ veriler tek bir ölçme aracıyla toplanmıştır. Yine yurt içinde yapılan eğitim araştırmalarında bu duruma sıklıkla rastlanmaktadır (Çiltaş, Güler ve Sözbilir, 2012; Ulutaş ve Ubuz, 2008). Veri analiz yöntem ve teknikleri açısından incelendiğinde, en fazla t-testinin $(\mathrm{f}=15 ; \% 38,5)$ kullanıldığı görülmüştür. Bu bulgu, eğitim alanında t-testi kullanımının araştırmacılar arasında eğiliminin en fazla olduğu teknikler olduğunu ortaya koyan çalışmalarla uyum içerisindedir (Erdem, 2011; Ozan ve Köse, 2014; Yalçın, Bilican, Kezer ve Yalçın, 2009; Sözbilir ve Kutu, 2008). Yeni tasarlanacak çalışmalar için, bulguların daha güvenilir ve tutarlı olması açısından verilerin farklı ölçme araçları ya da yöntemleriyle desteklenmesi önerilmektedir. Veri analizlerinde diğer analiz yöntem ve teknikleri kullanılmasının, nitel ve nicel analizlerin birlikte kullanılarak elde edilen bulguların birlikte değerlendirilmesinin alanyazına katkı sağlayacağı düşünülmektedir.

\section{Makalenin Bilimdeki Konumu}

Matematik ve Fen Bilimleri Eğitimi/Fizik, Kimya, Biyoloji, Fen Bilgisi Eğitimi

\section{Makalenin Bilimdeki Özgünlüğü}

Araştırma eğilimlerini belirlemeye yönelik çalışmalar, araştırmaların kalitesini artırmakta ve etkilidir (Paletz, Smith-Doerr ve Vardi, 2010; Millar ve Dillman, 2011). Çalışmaya değer ve gelişim sürecine katkı sağlayacak konuların belirlenmesine önemli 
YYÜ Eğitim Fakültesi Dergisi (YYU Journal of Education Faculty), 2021; 18(1)622-651,http://efdergi.yyu.edu.tr,

bir katkı sağlar (Alshamrani ve Aldahmash, 2020). Bu çalışmada da kavram karikatürü konulu makaleler yayın yılı, araştırma konusu, çalışma grubu, yöntemi veri toplama araçları ve veri analiz yöntemleri açısından incelenmiştir. Böylelikle araştırmacıların, kavram karikatürü konulu çalışmaların kapsam ve yöntemleri hakkında bilgi sahibi olmalarını sağlayacağı düşünülmektedir. Lee ve diğerlerinin (2004) de belirttiği gibi, bu çalışmanın alan yazındaki boşlukları ve yığılmaları vurgulayarak, araştırmacılara kendi çalışmalarında izleyecekleri yola karar vermeye yönelik fikirleri üretmede faydalı olacaktır. $\mathrm{Bu}$ çalışmanın araştırmacıların iş yükünü azaltacağı, alanda üzerine yoğunlaşılan ve eksik kalan noktaları bir arada görme fırsatı sunarak, rehberlik edebileceği düşünülmektedir.

\section{Kaynaklar}

Akaydın, Ş., \& Çeçen, M. A. (2015). Okuma becerisiyle ilgili makaleler üzerine bir içerik analizi. Ĕgitim ve Bilim, 40(178), 183-198.

Alkış Küçükaydın, M. (2019). The effect of concept cartoons used in science education to achievement: Meta-analysis study. Inonu University Journal of the Faculty of Education, 20(1), 220-233. DOI: 10.17679/inuefd.434352

Alshamrani, S. M. ve Aldahmash, A. H. (2020). 2011 ile 2017 Arasında ESERA bildirilerinde yayınlanan fen eğitimi araştırma makalelerinin sistematik bir değerlendirmesi. Ĕgitim ve Bilim, 45(202), 1-16.

Arık, R. S. \& Türkmen, M. (2009). Eğitim bilimleri alanında yayınlanan bilimsel dergilerde yer alan makalelerin incelenmesi. I. Uluslararası Eğitim Araştırmaları Kongresi 1-3 Mayıs. Çanakkale: 18 Mart Üniversitesi.

Atasoy, Ş. (2017). Kavram Karikatürü. Tatl1, Z. (Ed.). Kavram Öğretiminde Web 2.0. (s. 98-119). Ankara: Pegem Akademi.

Ateş, Ö. ve Ören, F. Ş. (2018). Elektrik konusunu hatırda tutma üzerine kavram karikatürleri ve haritalarının etkisi. Pegem Atıf İndeksi, 355-368.

Bahrani, T. \& Soltani, R. (2011). The pedagogical values of cartoons. Research on Humanities and Social Sciences, 1(4), 19-22.

Baysarı, E. (2007). Illkögretim düzeyinde 5. sinıf fen ve teknoloji dersi canlılar ve hayat ünitesi öğretiminde kavram karikatürü kullanımının öğrenci başarısına, fen 
tutumuna ve kavram yanılgılarının giderilmesine olan etkisi. Yayımlanmamış yüksek lisans tezi, Dokuz Eylül Üniversitesi Eğitim Bilimleri Enstitüsü, İzmir.

Birisçi, S., Metin, M. ve Karakaş, M., (2010). Pre-service elementary teachers’ views on conceptcartoons: A sample from Turkey. Middle-East Journal of Scientific Research, 5(2), 91-97.

Cavagnetto, A. R. (2010). Argument to foster scientific literacy: A review of argument interventions in K-12 science contexts. Review of Educational Research, 80(3), 336-371. http://dx.doi.org/10.3102/0034654310376953.

Cengizhan, S. (2011). Modüler öğretim tasarımıyla entegre edilmiş kavram karikatürleri hakkında öğretmen adaylarının görüşleri. Ĕ̌itim ve Bilim, 36(160), 93-104.

Ceylan, Ö. ve Atabek Yiğit, E. (2018). Analyzing the effect of concept cartoon usage on students' cognitive structures developments and science achievements through flow maps. Science Education International, 29(4), 238-249.

Chin, C., ve Teou, L. Y. (2009). Using concept cartoons in formative assessment: Scaffolding students’ argumentation. International Journal of Science Education, 31(10), 1307-1332.

Chin, C., ve Teou, L. Y. (2010). Formative assessment: Using concept cartoon, pupils' drawings, and group discussions to tackle children's ideas about biological inheritance. Journal of Biological Education, 44(3), 108-115.

Çalık, M., Ünal, S., Costu, B., \& Karataş, F. O. (2008). Trends in Turkish science education. Essays in Education, 24(4), 22-45.

Çetinkaya, E., \& Taşar, M. (2018). Examining the Argumentation Researches at the Science Education in Turkey. Hacettepe University Journal of Education, 33(2), 353-381.

Çiltaş, A., Güler, G., \& Sözbilir, M. (2012). Türkiye'de matematik eğitimi araştırmaları: Bir içerik analizi çalışması. Kuram ve Uygulamada Eğitim Bilimleri, 12(1), 565580.

Dalacosta, K., Kamariotaki-Paparrigopoulou, M., Palyvos, J. A., ve Spyrellis, N. (2009). Multimedia application with animated cartoons for teaching science in elementary education. Computers and Education, 52(4), 741-748. http://dx.doi.org/10.1016/j.compedu.2008.11.018 
YYÜ Eğitim Fakültesi Dergisi (YYU Journal of Education Faculty), 2021; 18(1)622-651,http://efdergi.yyu.edu.tr,

Deng, F., Chen, D. T., Tsai, C. C., \& Chai, C. S. (2011). Students' views of the nature of science: A critical review of research. Science Education, 95(6), 961-999.

Durmaz, B. (2007). Yapılandırıcı fen öğretiminde kavram karikatürlerinin öğrencilerin başarısı ve duyuşsal özelliklerine etkisi (Muğla ili Merkez İlçe örneği). Yayımlanmamış yüksek lisans tezi, Muğla Üniversitesi Fen Bilimleri Enstitüsü, Muğla.

Erdem, D. (2011). Türkiye'de 2005-2006 yılları arasında yayımlanan eğitim bilimleri dergilerindeki makalelerin bazı özellikler açısından incelenmesi: Betimsel bir analiz. Ĕgitimde ve Psikolojide Ölçme ve Değerlendirme Dergisi, 2(1), 140-147.

Evrekli, E. (2010). Fen ve teknoloji ögretiminde zihin haritası ve kavram karikatürü etkinliklerin ögrencilerin akademik başarılarına ve sorgulayıcı öğrenme beceri algılarına etkisi. Yayımlanmamış doktora tezi, Dokuz Eylül Üniversitesi Eğitim Bilimleri Enstitüsü, İzmir.

Evrekli, E. ve Balım, A. G. (2010). Fen ve teknoloji öğretiminde zihin haritası ve kavram karikatürü kullanımının öğrencilerin akademik başarılarına ve sorgulayıcı öğrenme becerileri algılarına etkisi. Batı Anadolu Ĕ̆itim Bilimleri Dergisi, 1(2), 76-98.

Genç, H. N. (2020). Fen bilgisi eğitimi alanında kavram karikatürü ile ilgili tezler üzerine bir içerik analizi: Türkiye örneği (2007-2019). Uluslararası Beşeri Bilimler ve Ë̆itim Dergisi, 6(13), 267-290.

Göktaş, Y., Küçük, S., Aydemir, M., Telli, E., Arpacık, Ö., Yıldırım, G. ve Reisoğlu, İ. (2012). Türkiye'de eğitim teknolojileri araştırmalarındaki eğilimler: 2000-2009 dönemi makalelerinin içerik analizi. Kuram ve Uygulamada Eğitim Bilimleri Dergisi, 12(1), 177-199.

Gülbahar, Y., \& Alper, A. (2009). Öğretim teknolojileri alanında yapılan araştırmalar konusunda bir içerik analizi. Ankara Üniversitesi Eğitim Bilimleri Fakültesi Dergisi, 42(2), 93-112.

Güngör, H. (2018). Fen ve teknoloji öğretiminde kavram karikatürü kullanımının ilköğretim 7. Sınıf ögrencilerin akademik başarılarına etkisi. Yayımlanmamış Yüksek Lisans Tezi, Necmettin Erbakan Üniversitesi Eğitim Bilimleri Enstitüsü, Konya. 
Jamal, S. N. B., Ibrahim, N. H. B., \& Surif, J. B. (2019). Concept cartoon in problembased learning: A systematic literature review analysis. Journal of Technology and Science Education, 9(1), 51-58.

Kabapınar, F. (2005). Yapılandırmacı Öğrenme Sürecine Katkıları Açısından Fen Derslerinde Kullanılabilecek Bir Öğretim Yöntemi Olarak Kavram Karikatürleri. Kuram ve Uygulamada Eğitim Bilimleri (KUYEB), 5(1), 101-146.

Kabapinar, F. (2009). What makes concept cartoons more effective? Using research to inform practice. Eğitim ve Bilim, 34(154), 104-118.

Karadağ, E. (2009). Türkiye'de ĕgitim bilimleri alanında yapılmış doktora tezlerinin tematik ve metodolojik açıdan incelemesi: Bir durum çalışması. Yayımlanmamış yüksek lisans tezi, Marmara Üniversitesi Eğitim Bilimleri Enstitüsü, İstanbul.

Karakuş, S. (2019). Fen Bilimleri Dersinde Kavram Karikatürü Kullanımının 7.Sınıf Öğrencilerinin Kütle-Ăgırlık Konusundaki Kavram Yanılgllarına Etkisi. Yayımlanmamış yüksek lisans tezi, Hacettepe Üniversitesi Eğitim Bilimleri Enstitüsü, Ankara.

Keogh, B. \& Naylor, S. (1996). Teaching and learning in science: A new perspective. Bera Conference, University of Lancester, UK.

Kirisçioğlu, S. ve Başdaş, E. (2007). Yapılandırmacı öğrenme ortamlarında fen ve teknoloji derslerinde kullanılabilecek kavram karikatürleri ve etkinlik örnekleri. Ĕ̆itimde Yeni Yönelimler IV: Yapılandırmacılık ve Öğretmen, Ankara: Özel Tevfik Fikret Okulları.

Korkut, T. Y. ve Şaşmaz Ören, F.(2018). Kavram Karikatürleriyle desteklenmiş bilimsel hikâyelerin öğrencilerin akademik başarıları, tutumları ve motivasyonları üzerine etkisi. Batı Anadolu Eğitim Bilimleri Dergisi, 9(1), 38-52.

Köseoğlu, F., Atasoy, B., Kavak, N., Akkuş, H., Budak, E., Tümay, H., Kadayıfçı, H., \& Taşdelen, U. (2003). Yapılandırmacı Öğrenme Ortamı için Bir Fen Ders Kitabı Nasıl Olmalı. Ankara: Asil Yayın Dağıtım.

Lederman, N. G. (2007). Nature of sciene: Past, present, and future. In Abell, S. K., \& Lederman, N. G. (Eds.), Handbook of research on science education (pp. 831879). Mahwah, NJ: Lawrence Erlbaum Associates. 
YYÜ Eğitim Fakültesi Dergisi (YYU Journal of Education Faculty), 2021; 18(1)622-651,http://efdergi.yyu.edu.tr,

Lee, Y., Driscoll, M. P., \& Nelson, D. W. (2004). The past, present, and future of research in distance education: results of a content analysis. American Journal of Distance Education, 18(4), 225-241. doi:10.1207/s15389286ajde1804_4

Long, S. \& Marson, K. (2003). Concept Cartoons. Hands on Science, 19(3), 22-23.

Martinez, Y. M. (2004). Does The K-W-L Reading Strategy Enhance Student Understanding in Honors High School Science Classroom. Unpublished masters thesis. Fullerton, California State University.

Millar, M. M. \& Dillman, D. A. (2011). Improving response to Web and Mixed-Mode Surveys. Public Opinion Quarterly, 75(2), 249-269.

Minárechová, M. (2014). Using a concept cartoon method to address elementary school students' ideas about natural phenomena. European Journal of Science and Mathematics Education, 4(2), 214-228.

Molina-Azorín, J. F., \& Cameron, R. A. (2015). History and emergent practices of multimethod and mixed methods in business research. In The Oxford handbook of multimethod and mixed methods research inquiry. Avaible at https://www.oxfordhandbooks.com/view/10.1093/oxfordhb/9780199933624.001. 0001/oxfordhb-9780199933624-e-29

Morris, M., Merritt, M., Fairchough, S., Birrell, N., \& Howitt, C. (2007). Trialling concept cartoons in early childhood teaching and learning of science. Teaching Science, 53(2), 42-45.

Murtiningrum, T., \& Ashadi, Mulyani, S. (2013). Pembelajaran kimia dengan problem solving menggunakan media e-learning dan komik ditinjau dari kemampuan berfikir abstrak dan kreativitas siswa. Jurnal Inkuiri, 2(3), 288-301.

Naylor, S., \& Keogh, B. (1999). Science on the Underground: An initial evaluation. Public Understanding of Science, 8, 1-18

Naylor, S., Keogh, B., \& Downing, B. (2007). Argumentation and primary science. Research in Science Education, 37(1), 17-39. http://dx.doi.org/10.1007/s11165005-9002-5

Öztuna Kaplan, A. ve Boyacıoğlu, N. (2012). Çocuk karikatürlerinde maddenin tanecikli yapısı. Türk Fen Eğitimi Dergisi, 10(1), 156-175.

Paletz, S., Smith-Doerr, L., \& Vardi, I. (2010). National Science Foundation workshop report: Interdisciplinary collaboration in innovative science and engineering 
YYÜ Eğitim Fakültesi Dergisi (YYU Journal of Education Faculty), 2021; 18(1)622-651,http://efdergi.yyu.edu.tr,

fields. Erişim adresi: https://www.bu.edu/sociology/files/2011/03/nsf-workshopreport.pdf

Samkova, L. \& Hospesova, A. (2015). Using Concept Cartoons to investigate future teachers’ knowledge. Konrad Krainer; Nad'a Vondrová. Proceedings of CERME 9 - Ninth Congress of the European Society for Research in Mathematics Education, Prague, Czech Republic pp. 3241-324.

Say, F. ve Özmen, H. (2018). Effectiveness of concept cartoons on 7th grade students' understanding of "the Structure and Properties of Matter". Türk Fen Eğitim Dergisi, 15(1),.1-24.

Selçuk, Z., Palancı, M., Kandemir, M., ve Dündar, H. (2014). Eğitim ve Bilim dergisinde yayınlanan araştırmaların eğilimleri: İçerik analizi. Eğitim ve Bilim, 39(173), 430-453.

Serttaş, S. ve Türkoğlu, A. Y. (2020). Diagnosing Students' Misconceptions of Astronomy Through Concept Cartoons. Participatory Educational Research, 7(2), 164-182.

Sexton, M., Gervasoni, A., \& Brandenburg, R. (2009). Using a Concept Cartoon to Gain Insight into Children's Calculation Strategies. Australian Primary Mathematics Classroom, 14(4), 24-28.

Sinanoğlu, K. (2017). Kavram karikatürleri ve kavramsal değişim metinlerinin 6. sınıf ögrencilerinin bilişsel yüküne, akademik başarısına ve kalıcılı̆̆ına etkisi. Yayımlanmamış Yüksek Lisan Tezi, Ordu Üniversitesi Fen Bilimleri Enstitüsü, Ordu.

Slack, N., Lewis, M., \& Bates, H. (2004). The two worlds of operations management research and practice. International Journal of Operations \& Production Management, 24(4), 372-387.

Sozbilir, M., \& Kutu, H. (2008). Development and current status of science education research in Turkey. Essays in Education, 24(3), 1-22.

Stephenson, P. \& Warwick, P. (2002). Using concept cartoons to support progression in students' understanding of light. Physics Education 37(2):135-141.

Şaşmaz Ören, F. (2009). Öğretmen adaylarının kavram karikatürü oluşturma becerilerinin dereceli puanlama anahtarıyla değerlendirilmesi. Education Sciences, 4(3), 994-1016. 
Şimşek, A., Özdamar, N., Uysal, Ö., Kobak, K., Berk, C., Kılıçer, T., \& Çiğdem, H. (2009). İkibinli yıllarda Türkiye'deki eğitim teknolojisi araştırmalarında gözlenen eğilimler. Kuram ve Uygulamada Ĕ̈itim Bilimleri Dergisi, 9(2), 115-120.

Temel, S., Şen, Ş., \& Yılmaz, A. (2015). Validity and reliability analyses for chemistry self-concept inventory. Journal of Baltic Science Education, 14(5), 599-606.

Tokcan, H. (2015). Sosyal Bilgilerde Kavram Öğretimi (1.Basım), Ankara: Pegem Akademi Yayıncılık.

Ulutaş, F., \& Ubuz, B. (2008). Matematik eğitiminde araştırmalar ve eğilimler: 2000 ile 2006 yılları arası. Ilkogretim Online, 7(3), 614-626.

Yalçın, N., Bilican, S., Kezer, F. \& Yalçın, Ö. (2009). Hacettepe üniversitesi eğitim fakültesi dergisinde yayımlanan makalelerin niteliği: İçerik analizi. http:// oc.eab.org.tr/egtconf/pdfkitap/pdf/488.pdf adresinden erişilmiştir.

Yalçın, S., Yavuz, H. Ç., \& Dibek, M. İ. (2016). En yüksek etki faktörüne sahip eğitim dergilerindeki makalelerin içerik analizi. Eğitim ve Bilim, 40(182), 1-28.

Yavuz, S. \& Büyükekşi, C. (2011). Kavram karikatürlerinin 1s1-sıcaklık kavramlarının öğretiminde kullanılması. Karaelmas Fen ve Mühendislik Dergisi, 1(2), 25-30.

Yin, Y. K., \& Fitzgerald, R. (2017). Peer learning with concept cartoons enhance critical thinking and performance in secondary school economics. Journal of Economic Education Research, 18(1), 1-13.

Yokuş, G., \& Ayçiçek, B. (2019). Kavram karikatürlerinin fen eğitimi dersi akademik başarısı üzerindeki etkisini belirlemeye yönelik bir meta-analiz çalışması. Pamukkale Üniversitesi Ĕ̈itim Fakültesi Dergisi, 49, 223-246. 


\section{Summary}

\section{Statement of Problem}

Concept cartoons are drawings that have more than one correct answer, consisting of conversations between different characters, aiming to help learners reach a scientific mindset (Karakuş, 2019). Studies in the literature show that concept cartoons increase academic achievement (Akbaş and Toros, 2016; Yin and Fitzgerald, 2017) and are effective in identifying and eliminating misconceptions (Atasoy and Ergin, 2017; Serttaş and Türkoğlu, 2020). Also, it was observed that the concept cartoons increased students' interest in the lesson (Jamal, Ibrahim, and Surif, 2019; Kaptan and İzgi, 2014), and their critical thinking and questioning skills improved (Jamal, Ibrahim, and Surif, 2019; Yin and Fitzgerald, 2017). It has been determined that it makes easier to understand concepts especially in mathematics, physics, and science lessons (Ateş and Ören, 2018; Karakuş, 2019). It is known to be effective in revealing their prior knowledge or incorrect information about the subject and encouraging students to research (Naylor and Keogh, 1999).

Concept cartoons are a topic of great interest among science educators. However, the study topics that attract attention among researchers can cause studies to show similar characteristics over time and the literature to repeat itself continuously (Deng, Chen, Tsai, \& Chai, 2011; Lederman, 2007). To prevent this, it is necessary to know where our country is in this field, the stages it has taken and the methods it has followed. For these reasons, in this study, concept cartoons in science education in Turkey aimed to identify trends in the use of the subject article. In this way, it is thought that this study will guide by offering the opportunity to see the missing points in the field together.

\section{Method}

Descriptive content analysis, which is defined as reviewing and organizing studies on a particular subject, and evaluating general trends and research results in a descriptive dimension (Çalık and Sözbilir, 2014; Selçuk, Palancı, Kandemir, and Dündar, 2014), was preferred as a method in the study.

The articles to be examined in the study were determined by the criterion sampling method. The following criteria were sought in the articles:

The study is related to science education 
- $\quad$ The study was published in Turkish or English

- $\quad$ The study contains “concept cartoon” expression

- $\quad$ The study is a research article

- $\quad$ The full text of the study was available

Thirty-three articles meeting these criteria from the screening results were included in the study.

After the articles to be reviewed were determined, the full texts of the articles were reviewed over and over, and codes and themes were created by the research questions. The codes were determined by examining similar studies in the literature and were developed as the number of articles examined increased. The codes that were categorized afterward were gathered under similar themes.

Findings, Discussion and Conclusion

As a result of the analysis, it is seen that concept cartoons have started to take place in science education literature since 2008 and continue today. It was seen that most articles on concept cartoons were published in 2013.

It was determined that the main purpose of the articles is to examine the effect of teaching with concept cartoons on a variable. The variables most investigated in the articles were students' academic achievement $(\mathrm{f}=14 ; 35.9 \%)$ and conceptual understanding ( $\mathrm{f}=7 ; 17.9 \%$ ). Karadağ (2009) points out that academic achievement in the field of education is the most studied theme. New studies can be designed to determine the relationships between concept cartoons and different variables such as scientific process skills, critical thinking skills, epistemological beliefs.

Concept cartoons were mostly used between 4-6 weeks in line with the research purpose in reviewed articles. However, it is stated in the literature that concept cartoons should be used for at least eight weeks to affect the academic success (Yokuş and Ayçiçek, 2020). In this case, it is recommended to apply concept cartoons for longer periods in new studies to obtain more reliable results.

It was seen that concept cartoons were used in science and technology lessons in most of the articles, there were middle school students as a sample. In terms of size, it was observed that most small samples of 50-100 people were used. In general, the studies conducted in the field of education in Turkey is known to take place in small 
samples (Arik and Turkmen, 2009; Meteors et al., 2012; Selcuk, Palanci, Kandemir and Dundar, 2014; Yalcin, Yavuz and Dibek, 2016).

In the methodological review, the articles were mostly designed in a quantitative method, in a quasi-experimental design. The number of studies using qualitative and mixed methods is quite limited. This situation is frequently found in Turkey in educational research (Arık and Türkmen, 2009; Göktaş et. al., 2012; Şimşek et. al., 2008). To better illuminate the effects of using concept cartoons, it may be suggested to use qualitative methods in new studies.

The trend in the data collection phase was on multiple-choice questions and Likert type scales. Also, data in most of the studies ( $\mathrm{f}=23$; $59.0 \%$ ) were collected by a single measurement tool. Again, this situation is frequently encountered in educational research conducted in the country (Çiltaş, Güler, and Sözbilir, 2012; Ulutaş and Ubuz, 2008). For studies to be designed, it is recommended to support the data with different measurement tools or methods in order to make the findings more reliable and consistent.

In the data analysis, it was seen that the researchers mostly preferred the t-test. This finding is in accordance with studies that reveal that the use of t-tests in the field of education is the most prone techniques among researchers (Erdem, 2011; Ozan and Köse, 2014; Yalçın, Bilican, Kezer, and Yalçın, 2009; Sözbilir and Kutu, 2008).

\section{Ek1: İncelenen makalelerin listesi}

M1. Yurttadur, Ş. ve Pehlivan, M. (2020). Fen bilimleri dersinde karikatür kullanımının öğrencilerin erişilerine etkisi. Journal of Steam Education, 3(1), 2031.

M2. Artun, H., Gülseven, E. ve Temur, A. (2019). Beşinci sınıf öğrencilerinin biyoçeşitlilik konusunu anlamaları üzerine kavram karikatürlerinin etkisi. Bolu Abant İzzet Baysal Üniversitesi Ĕ̆itim Fakültesi Dergisi, 19(3), 721-731.

M3. Gölgeli, D. ve Saraçoğlu, M. (2019). Düşün-eşleş-paylaş tekniği ile birlikte kullanılan kavram karikatürlerinin öğrencilerin akademik başarıları ile fen ve teknoloji dersine olan tutumlarına etkisinin incelenmesi. Erciyes Journal of Education, 3(1), 68-86. 
M4. Karakırık, G. ve Kabapınar, F. (2019). Kavram karikatürü temelinde tasarlanan öğretimin 9. sınıf öğrencilerinin atom yarıçapı kavramını öğrenmelerine etkisi. Türkiye Kimya Derneği Dergisi Klsım C: Kimya Ĕ̆itimi, 4(2), 113-144.

M5. Özsevgeç, L. C., Yurtbakan, E. ve Uludüz, Ş. (2019). İlkokul dördüncü sınıf öğrencilerinin "kütle ve ağırlık” kavramlarına yönelik yanılgılarının giderilmesinde kavram karikatürünün etkisi. Fen Bilimleri Öğretimi Dergisi, 7(1), 51-67.

M6. Korkut, T. Y. ve Ören, F. Ş. (2018). Kavram karikatürleriyle desteklenmiş bilimsel hikâyelerin öğrencilerin akademik başarıları, tutumları ve motivasyonları üzerine etkisi. Batı Anadolu Eğitim Bilimleri Dergisi, 9(1), 38-52.

M7. Yurtyapan, E., Kandemir, N. ve Kandemir, Ş. (2017). Kavram karikatürü destekli fen öğretimi hakkında öğretmen adaylarının görüşleri. Ege Eğitim Dergisi, 18(2), 738-773.

M8. Aydın, G. ve Özyürek, C. (2017). Işık kirliliği konusunun bilgisayar destekli kavram karikatürleriyle öğretimi. Journal of Inquiry Based Activities, 4(2), 54-71.

M9. Yıldırım, N., Tepe, M., Kuş, S. ve Biberoğlu, B. (2016). Kimyasal denge konusundaki kavram yanılgılarını belirlemeye yönelik kavram karikatürü destekli iki aşamalı test geliştirilmesi ve uygulanması. Bayburt Eğitim Fakültesi Dergisi, 10 (2), 534-547.

M10. Duman, M. ve Avcı, G. (2016). Sekizinci sınıf öğrencilerinin maddenin halleri ve 1S1 ünitesine yönelik kavram yanılgıları. Uşak Üniversitesi Ĕ̆itim Araştırmaları Dergisi, 2(3) , 129-165. DOI: 10.29065/usakead.256383

M11. Balım, A. G., Çeliker, H. D., Türkoğuz, S., Evrekli, E., \& Ekici, D. İ. (2015). Kavram karikatürleri destekli probleme dayalı öğrenme yönteminin öğrencilerin kavramsal anlama düzeyleri ile problem çözme becerisi algıları üzerine etkisi. Journal of Turkish Science Education, 12(4), 53-76.

M12. Özge, E. R. ve Ören, F. Ş. (2015). Fen ve teknoloji dersi 7. sınıf "1şık" ünitesinde alternatif değerlendirme yaklaşımları temelli öğretimin öğrencilerin akademik başarı ve tutumları üzerine etkisi. Celal Bayar Üniversitesi Sosyal Bilimler Dergisi, 13(4),135-164.

M13. Evrekli, E. ve Balım, A. G. (2015). Fen derslerinde animasyon destekli kavram karikatürleri kullanımının altıncı sınıf öğrencilerinin sorgulayıcı öğrenme becerileri algılarına etkisi. Batı Anadolu Eğitim Bilimleri Dergisi, 6(11), 109-136. 
M14. Aydoğdu, B., Duban, N., \& Evrekli, E. (2015). Sınıf öğretmeni adaylarının Fen ve teknoloji öğretimi-I dersinde hazırladıkları kavram karikatürlerinin değerlendirilmesi. Dicle Üniversitesi Ziya Gökalp Eğitim Fakültesi Dergisi, 26, 100-120.

M15. Ocak, İ., Güleç Islak, F. ve Ocak, G. (2015). İlkokul 4. sınıf fen bilimleri dersinde kavram karikatürü kullanımının akademik başarıya etkisi. Bartın University Journal of Faculty of Education, Special edition, 119-132.

M16. Türkoguz, S. ve Cin, M. (2014). Effects of argumentation based concept cartoon activities on students' scientific process skills. Mersin University Journal of the Faculty of Education, 10(2), 142-156.

M17. Çïnici, A., Özden, M., Akgün, A , Herdem, K , Deniz, Ş. ve Karabiber, H . (2014). Kavram karikatürleriyle desteklenmiş argümantasyon temelli uygulamaların etkinliğinin incelenmesi. Adlyaman Üniversitesi Sosyal Bilimler Enstitüsü Dergisi , 18, 571-596. DOI: 10.14520/adyusbd.839

M18. Demirel, R. ve Aslan, O . (2014). The effect of science and technology teaching promoted with concept cartoons on students' academic achievement and conceptual understanding. Eğitimde Kuram ve Uygulama, 10(2), 368-392. Retrieved from https://dergipark.org.tr/tr/pub/eku/issue/5460/74070

M19. Taşlıdere, E. (2014). Kavramsal değişim yaklaşımının doğru akım devreleri konusundaki kavram yanılgılarının giderilmesine etkisi. Bartın University Journal of Faculty of Education, 3(1) , 200-223.

M20. Atasoy, Ş., Tekbıyık, A. ve Gülay, A. (2013). Beşinci sınıf öğrencilerinin ses kavramını anlamaları üzerine kavram karikatürlerinin etkisi. Journal of Turkish Science Education, 10(1), 176-196.

M21. Türkoğuz, S. ve Cin, M. (2013). Argümantasyona dayalı kavram karikatürü etkinliklerinin öğrencilerin kavramsal anlama düzeylerine etkisi. Dokuz Eylül Üniversitesi Buca Eğitim Fakültesi Dergisi, 35, 155-173.

M22. Uzoğlu, M., Yıldız, A., Demir, Y. ve Büyükkasap, E. (2013). Fen bilgisi öğretmen adaylarının 1şıkla ilgili kavram yanılgılarının belirlenmesinde kavram karikatürlerinin ve açık uçlu soruların etkililiklerinin karşılaştırılması. Journal of Kirsehir Education Faculty, 14(1), 367-388. 
M23. Taşlidere, E. (2013). Kavram karikatürleri ile zenginleştirilmiş çalışma yapraklarının öğrencilerin geometrik optik konusundaki kavramsal anlamalarına etkisi. Ĕ̌gitim ve Bilim, 38(167), 144-161.

M24. Şahin, Ç., Bülbül, E. ve Durukan, Ü. (2013). Öğrencilerin gök cisimleri konusundaki alternatif kavramlarının giderilmesinde kavramsal değişim metinlerinin etkisi . Journal of Computer and Education Research, 1(2), 38-64.

M25. Aydın, G. ve Balım, A. G. (2013). Öğrencilerin "hücre bölünmesi ve kalıtım" konularına ilişkin kavram yanılgıları. Eğitim ve Öğretim Araştırmaları Dergisi, 2(1), 338-348.

M26. Ören, F. Ş., Karatekin, P., Erdem, Ş. ve Ormanc1, Ü. (2012). Öğretmen adaylarının bitkilerde solunum-fotosentez konusundaki bilgi düzeylerinin kavram karikatürleriyle belirlenmesi ve farklı değişkenlere göre analizi. Ahi Evran Üniversitesi Kırşehir Eğitim Fakültesi Dergisi, 13(3), 155-174.

M27. Erdoğan, A. ve Özsevgeç, L. C. (2012). Kavram karikatürlerinin öğrencilerin kavram yanılgılarının giderilmesi üzerindeki etkisi: Sera etkisi ve küresel 1sınma örneği. Turkish Journal of Education, 1(2), 38-50.

M28. Demir, Y., Uzoğlu, M. ve Büyükkasap, E. (2012). Fen bilgisi öğretmen adaylarının kuvvet ve hareket ile ilgili belirlenmesinde kullanılan karikatürlerin ve çoktan seçmeli soruların etkililiğinin karşılaştırılması. Ĕgitim ve Öğretim Araştırmaları Dergisi, 1(1), 88-102.

M29. Yavuz, S. ve Büyükekşi, C. (2012). Usage of concept cartoons in teaching of heattemperature topic. Karaelmas Science and Engineering Journal, 1(2), 25-30.

M30. Gölgeli, D. ve Saraçoğlu, S. (2011). Fen ve teknoloji dersi “Işık ve Ses” ünitesinin öğretiminde kavram karikatürlerinin kullanımının öğrencilerin akademik başarısına etkisi. Erciyes Üniversitesi Sosyal Bilimler Enstitüsü Dergisi, 1(31), 113-124.

M31. İnel, D. ve Balım, A. G. (2011). Kavram karikatürleri destekli probleme dayalı öğrenme yönteminin ilköğretim 6. sınıf öğrencilerinin fen öğrenmeye yönelik motivasyonlarına etkisi. Uşak Üniversitesi Sosyal Bilimler Dergisi, 4(1), 169-188.

M32. Evrekli, E., Balım, A. ve İnel, D. (2011). Fen öğretiminde kavram karikatürleri ve zihin haritalarının birlikte kullanımının etkileri üzerine bir araştırma. Necatibey Ĕ̌itim Fakültesi Elektronik Fen ve Matematik Eğitimi Dergisi, 5(2), 58-85. 
M33. Çiçek, T. ve Öztürk, M. (2011). İlköğretim 6. sınıf fen ve teknoloji dersinde kavram karikatürü uygulamalarının akademik başarı ve öğrenmenin kalıcılığına etkisi. Manisa Celal Bayar Üniversitesi Eğitim Fakültesi Dergisi, 1(1) , 1-20.

M34. Evrekli, E. ve Balım, A. (2010). Fen ve Teknoloji öğretiminde zihin haritası ve kavram karikatürü kullanımının öğrencilerin akademik başarılarına ve sorgulayıcı öğrenme becerileri algılarına etkisi. Batı Anadolu Eğitim Bilimleri Dergisi, 1(2) , 76-98.

M35. Seçgin, F., Yalvaç, G. ve Çetin, T. (2010, November). İlköğretim 8. sinıf öğrencilerinin karikatürler aracılığıyla çevre sorunlarına ilişkin algıları. In International Conference on New Trends in Education and Their Implications, 11(13), 391-398.

M36. İnel, D., Balım, A. G. ve Evrekli, E. (2009). Fen öğretiminde kavram karikatürü kullanımına ilişkin öğrenci görüşleri. Necatibey Eğitim Fakültesi Elektronik Fen ve Matematik Ĕ̈itimi Dergisi, 3(1),1-16.

M37. Akamca, G, Hamurcu, H. (2009). Analojiler, kavram karikatürleri ve tahmingözlem-açıklama teknikleriyle desteklenmiş fen ve teknoloji eğitimi. Education Sciences, 4(4) , 1186-1206.

M38. Balım, A. G., İnel, D. ve Evrekli, E. (2008). Fen öğretiminde kavram karikatürü kullanımının öğrencilerin akademik başarılarına ve sorgulayıcı öğrenme becerileri algılarına etkisi. Ilkogretim Online, 7(1), 188-202.

M39. Köse, E. Ö. (2008). Biyoloji eğitiminde karikatür destekli öğretimin öğrenci başarısına etkisi. Çă̆daş Ĕgitim Dergisi, 33(356), 14-21. 